\title{
Making Sense of Cents:
}

\section{An Examination of Firms That Marginally Miss or Beat Analyst Forecasts}

\author{
Sanjeev Bhojraj \\ Paul Hribar \\ Johnson Graduate School of Management \\ Cornell University, Ithaca, NY \\ Marc Picconi \\ Kelley School of Business \\ Indiana Univesity, Bloomington, IN
}

February 3, 2006

We thank Thomson Financial Services Inc. for providing earnings per share forecast data, available through the Institutional Brokers Estimate System (I/B/E/S). The data have been provided as part of a broad academic program to encourage earnings expectation research. We gratefully acknowledge the insightful comments and suggestions made by Jeff Abarbanell, Marty Butler, Nick Dopuch, Charles Lee, Bob Libby, Bob Lipe, Jeff Payne, Scott Richardson, Siew Hong Teoh, Wayne Thomas, Charles Wasley, Ross Watts, Jerry Zimmerman, and seminar participants at Binghamton University, Cornell University, the University of Illinois, The University of Minnesota, The University of North Carolina, The University of Oklahoma, the University of Rochester, and Washington University in St. Louis. 


\title{
Making Sense of Cents: \\ An Examination of Firms That Marginally Miss or Beat Analyst Forecasts
}

\begin{abstract}
This paper examines the short and long run performance implications of managing earnings to exceed market expectations. In particular, we examine the performance differences between two groups of firms: (1) firms that marginally exceed consensus forecasts but manage earnings upwards and (2) firms that miss consensus forecasts but do not manage earnings. We choose these two groups because they maximize the likelihood that earnings management activities undertaken by the firm would be able to move the firm from missing the earnings benchmark to beating it. In comparing the performance of these two groups, we find that using accruals or cutting discretionary expenditures to beat expectations results in a short-term positive impact on stock price, but adversely affects the firm in the long-term. We also examine whether managers behave as if they are cognizant of this trade-off and take actions to capitalize on the short-term positive performance impact of beating expectations through earnings management. We find that firms that manage earnings to exceed analyst expectations have significantly greater equity issuances and insider selling in the following year when compared with not only firms that missed expectations but also firms that beat expectations without managing earnings.
\end{abstract}




\section{Introduction}

Recent work suggests that there is pressure on firms to avoid missing earnings forecasts, and that this pressure has intensified in recent years (e.g. Barth, Elliott, Finn 1999; Brown 2001; Kasznik and McNichols 2002). Consequently, there is a growing body of evidence showing that a disproportionate number of firms meet or slightly beat analyst forecasts than would be expected by chance (Degeorge, Patel, Zeckhauser 1999; Payne and Robb 2000; Burgstahler and Eames 2002), and that the frequency with which firms exceed these forecasts has been increasing with time (Brown 2001). A recent survey by Graham, Harvey, and Rajgopal (2004) provides strong evidence that managers are willing to sacrifice economic value to meet short run earnings objectives. For example, they report that a majority of managers would forego a positive NPV project if it would cause them to fall short of the current quarter consensus forecast. In addition, Baber, Fairfield, and Haggar (1991) show that concerns regarding reported income affect expenditures on R\&D, and Bhojraj and Libby (2004) find that managers faced with a stock issuance more often choose projects that they believe will maximize short-term earnings (and price) as opposed to total cash flows.

A related body of research investigates the reasons why managers are motivated to meet or beat expectations (see, for example, Bartov, Givoly, Hayn 2002; Kasznik and McNichols 2002; Skinner and Sloan 2002; Graham et al. 2004). One finding from this line of research is that there appears to be a valuation premium associated with meeting or beating analyst forecasts, i.e., firms that successfully meet or beat analyst forecasts earn higher returns than would be expected given the information contained in current earnings. A second explanation is provided by Skinner and Sloan (2002), who show that missing expectations even by a small amount can trigger a disproportionately large negative stock price response by the market, 
suggesting that firms will be motivated to take steps to avoid an 'earnings torpedo.' Finally,

Graham et al. (2004) report that the most frequently cited reasons managers give for trying to beat benchmarks are to build credibility with the capital markets, to maintain or increase stock price, and to preserve managerial reputation. With respect to missing benchmarks, managers were most concerned that it created uncertainty about future prospects.

If, in fact, managers are willing to sacrifice future earnings, through accounting or cash flow-based earnings management, to meet short term earnings benchmarks, then there should be long term performance consequences associated with these choices. However, there is little empirical research that has documented the long-term implications of this behavior. In this paper, we address this issue by examining three research questions. First, do firms that indulge in myopic behavior enjoy short term benefits from managing earnings to exceed an earnings benchmark? Second, are there long run negative consequences associated with managing earnings to exceed benchmarks? Finally, do managers that act myopically to beat an earnings benchmark take actions to capitalize on this behavior? ${ }^{1}$

To examine these questions we focus primarily on two particular subsets of firms. One group consists of firms that marginally beat consensus forecasts (by one cent) and manage earnings upwards and the other group consists of firms that marginally miss consensus forecasts (by one cent) but do not manage earnings. ${ }^{2}$ We use accruals, R\&D expense, and advertising

\footnotetext{
${ }^{1}$ While the term managerial myopia often reflects managerial opportunism that is detrimental to current shareholders, this need not be the case. In our study, we use the term myopia to reflect any activities that boost short run earnings at the expense of long run earnings (i.e. accruals and discretionary expenditures). For example, if a firm is planning on issuing equity, then increasing current earnings might benefit the current shareholders in that they will receive more cash for the shares that are issued. See Bhojraj and Libby (2005) for a more detailed discussion of this issue.

${ }^{2}$ Of course, earnings management is not necessary for a firm to beat expectations. The sample of firms that beat by one cent includes (1) firms that would have missed but managed earnings through accruals or reductions in discretionary expenditures in order to beat, (2) firms that would have missed but guided analysts downward early in the quarter in order to beat by one cent, and (3) firms that did not have to take any overt actions in order to beat by one cent (i.e. they would have beaten by one penny or more without any earnings management or guidance). We
} 
expense to capture the discretion that firms have in meeting the consensus forecast. ${ }^{3}$ We choose these two particular subsamples because they maximize the likelihood that earnings management activities undertaken by the firm would be able to move the firm from missing the earnings benchmark to beating it. ${ }^{4}$ For example, a firm that beats by one cent but has a significant decrease in $R \& D$ or advertising expenditures or reports a significant amount of income increasing accruals likely would have missed expectations without these transactions. In contrast, a firm that misses by only one penny but continues investing in R\&D or advertising and has conservative accruals likely could have beaten the benchmark had they cut these expenditures.

A comparison of these two groups of firms speaks directly to the economic consequences of the tradeoff that managers face when they manage earnings to exceed analyst forecasts. On the one hand, beating forecasts increases contemporaneous returns and a consecutive string of such positive surprises can increase the valuation premium that a firm receives (Kasznik and McNichols 2002), and avoid a potentially drastic reduction in stock price associated with missing a forecast (Skinner and Sloan 2002). On the other hand, cutting discretionary expenditures or managing accruals upward will induce a transitory component to earnings that increases the likelihood that future earnings will reverse, and future performance will suffer. While accruals will often reverse within one year, cutting discretionary expenditures is potentially even more

are only interested in the first group of firms. To the extent that our partition captures firms of the second or third type, it will reduce the power of our tests.

${ }^{3}$ We do not examine expectations management as a mechanism to exceed analyst forecasts. Although earnings guidance shifts the timing of the earnings surprise, they should not affect future profitability since no economic construct has changed (i.e. unlike accruals and discretionary expenditures, forecast guidance does not affect the earnings of the current period, and should not affect future earnings, ceteris paribus).

${ }^{4}$ Prior research has examined the association between earnings surprises and accruals (e.g. Collins and Hribar 2000; Defond and Park 2001) in the extreme earnings surprise groups. We do not examine these groups as it is unreasonable to expect that a firm in an extreme earnings surprise decile would be able to qualitatively alter their earnings surprise (i.e. move from negative earnings surprise to a positive earnings surprise) via any type of earnings management. Moreover, these studies have focused on the groups where the signals are in the same direction, whereas we are interested in the tradeoff between reporting a small positive earnings surprise and taking potentially myopic actions. 
problematic because to the extent that these expenditures are positive NPV investments intended to generate long-term earnings, the persistence of earnings is reduced even further. ${ }^{5}$ The firms that miss expectations but report high quality earnings provide an interesting comparison group because they represent the other side of the tradeoff. In particular, it appears that these firms have financial statement characteristics that would allow them to exceed the benchmark, but for some reason have chosen not to do so. Thus, they are likely to have negative stock returns at the earnings announcement, but high quality earnings, which would reflect positively on their longterm prospects.

Our results show that in the short term, firms using accruals or discretionary expenditures to beat a forecast outperform firms that miss expectations but have high quality earnings. In the long run, however, these firms underperform the firms that missed expectations with high quality earnings. Examining the components separately, we find that accruals and R\&D contribute to the superior performance of the firms that miss expectations, but that advertising expense either has no effect or works in the opposite direction. We also find that firms beating expectations with low quality earnings show a reduction in ROA at the one year horizon, followed by a flat ROA over the next two years, while firms that missed expectations with high quality earnings have a flat ROA in the first year and significantly positive increases in ROA in years 2 and 3.

After observing the patterns in future earnings and stock returns, we then examine whether managers take actions that reflect an understanding of the short and long run implications of beating expectations through earnings management. If, in fact, managers act myopically and sacrifice long-run earnings in order to meet a short-run earnings benchmark, then

\footnotetext{
${ }^{5}$ Stated differently, reductions in value generating discretionary expenditures will have two effects on earnings persistence. First, an increase in earnings generated by cutting these expenses will be less persistent (i.e. the increase cannot be permanent) because the expenditures are bounded at zero. Second, future earnings will be reduced because of the lost income associated with the investment in R\&D or advertising.
} 
we would expect their actions to reflect this tradeoff. Theoretical models such as Stein (1989) and Bar-Gill and Bebchuk (2003) suggest that firms that are planning to issue equity will be more likely to behave myopically or misreport corporate performance. Bar-Gill and Bebchuk (2003) also find that managerial selling will increase when managers misreport. Consistent with these models, our results show that firms that beat forecasts with low quality earnings are significantly more likely to issue equity in the following year and exhibit significantly greater insider selling. These results hold regardless of whether they are compared to the firms that miss forecasts with high quality earnings or to the firms that beat forecasts but with high quality earnings. This is finding suggests that managers are aware of the short and long term implications of beating forecasts with low quality earnings and take actions accordingly.

Our paper contributes to the literatures on benchmark beating and managerial myopia, and our findings are particularly germane in light of the Graham et al. (2004) survey, where managers report a willingness to forego positive NPV projects in order to meet consensus forecasts. Our results indicate that while there are short-term benefits to a strategy of beating expectations using earnings management, there are also adverse long-term effects. The results suggest that a long-term investor is likely to be better off investing in a firm that marginally misses expectations without managing earnings than investing in one that beat expectations through earnings management.

We also provide empirical evidence that managers of these firms appear to understand these tradeoffs, in that they are significantly more likely to take actions that capitalize on the short term price benefits associated with beating the benchmark. This evidence is consistent with the survey and experimental evidence that suggests managers are willing to take myopic actions to exceed earnings benchmarks. 
Finally, we contribute to the literature on earnings management by extending the measure of earnings quality beyond accruals to include cash-based measures of discretionary expenditures. This enhancement appears to improve the discriminating ability of the earnings quality signal, especially at longer horizons. The inclusion of cash based earnings management improves the ability of the measure to predict future performance over the two and three-year horizons, reflecting the lag between the spending on these activities and the realization of benefits. ${ }^{6}$ This suggests that researchers might improve the power of models intended to capture earnings management by extending these models beyond total and discretionary accruals.

The rest of the paper is organized as follows. In the next section we discuss the data and research design. In section III we discuss the results and in section IV we give a summary and our conclusions.

\section{Sample and data}

The initial sample consists of firm-year observations drawn from the I/B/E/S database of analysts from 1988 to 2001, which allows us to compute accruals using the statement of cash flows (see Hribar and Collins 2002). To ensure consistency between actual earnings and analysts' expectations, we obtain both the forecast and reported earnings from the $\mathrm{I} / \mathrm{B} / \mathrm{E} / \mathrm{S}$ database. All other financial data are obtained from Compustat, while price and returns data are collected from the CRSP database. To ensure that our results are not biased by micro-cap or penny stocks, firms with assets less than $\$ 10$ million or that have a share price less than $\$ 5$ are dropped from the sample. We also drop firms that have a Compustat and I/B/E/S report date that are more than 5 days apart. Finally, we drop utilities and banks from our analysis, since their financial statements tend to be very different from other firms. We focus only on the annual

\footnotetext{
${ }^{6}$ This horizon is different from accruals which tend to reverse in the following year, and therefore show a significant drop-off in their ability to predict future performance at the two and three year horizons (see Sloan 1996).
} 
(fourth quarter) earnings because the majority of accrual adjustments occur in the fourth quarter (see, e.g. Collins and Hribar 2000) and R\&D / advertising expense are not available on a quarterly basis for approximately $25 \%$ of our sample.

We classify firms into categories based on the difference between actual earnings and analysts' expectations. Since management of cash based expenditures (R\&D and advertising) has to be carried out before fiscal year end, the manager's target would be the expectation in place during that period. We therefore use the consensus forecast as of the second month of the last quarter of each fiscal year as our proxy for the market expectation. This will allow the manager approximately one month to carry out cash-based earnings management. ${ }^{7}$ In our analysis, firms that miss expectations by one cent are referred to as "missers", firms that exactly meet expectations are referred to as "meeters" and firms that beat by one cent are referred to as "beaters." The reason for using firms that miss or beat by only one cent is that we are interested in maximizing the likelihood that a firm that beats (misses) would have missed (beaten) had they not (had they) increased earnings through accruals or reductions in discretionary expenditures. ${ }^{8}$ Our full sample consists of 30,651 observations, with 1,390 firms missing by one cent and 2,125 firms beating by one cent. We use analyst forecast errors measured in cents per share, because this measure is widely reported and disseminated, and is claimed by managers to be the earnings number that they are most concerned with managing towards (Graham et al. 2004).

\footnotetext{
${ }^{7}$ While cash based earnings management has to be carried out prior to the fiscal year-end, accruals based management could be done subsequent to the year-end. To test the robustness of our results we carry out our analysis by using the most recent consensus forecast reported at least one week in advance of the earnings announcement date as our measure of expectation. We drop all forecasts within 5 days of the earnings report date to ensure that the forecast is not tainted by whisper numbers. The results using this approach are qualitatively the same.

${ }^{8}$ We also conducted the analysis using groups that include beating (missing) by one or two cents per share and obtain similar results.
} 
To carry out our analysis, we use raw forecast data (provided upon request by I/B/E/S) unadjusted for stock splits. The standard I/B/E/S dataset reports analyst forecasts that are adjusted for splits and based on shares outstanding today along with a split factor. The problem is that $\mathrm{I} / \mathrm{B} / \mathrm{E} / \mathrm{S}$ rounds the estimate to the nearest cent. So an analyst estimate of $\$ 0.06$ and reported earnings of $\$ 0.07$ would both be reported as 2 cents after a 3:1 split. Consequently, use of the standard I/B/E/S database results in a disproportionate number of firms that exactly meet expectations. More problematic, however, is the fact that these firms have an ex-post performance bias in that they tend to experience stock splits in the future. Consequently, using the standard I/B/E/S database results in an empirical anomaly in that firms that exactly meet expectations significantly outperform firms that either just beat or firms that just miss (see Diether, Malloy and Scherbina (2002) for further discussion of this problem).

Figure 1 shows the distribution of earnings relative to analyst expectations for our entire sample. Consistent with prior research, the number of firms marginally beating expectations exceeds the number of firms marginally missing them. Although the discontinuity is not as pronounced as in studies that use zero earnings, zero earnings changes, or price scaled analyst forecasts as the benchmark, there does appear to be a greater tendency to exactly meet or beat by one cent, relative to what would be expected by chance.

Table 1 provides descriptive statistics for the firms in our sample. Panel A shows different firm characteristics by earnings position. Consistent with earlier research, firms that miss analyst forecasts ( $<-1$ and -1 groups) appear to have a higher book to market ratio, lower return on assets and lower $\mathrm{P} / \mathrm{E}$ ratios than firms beating expectations ( 1 and $>1$ groups). This highlights the increased importance of beating forecasts for younger, growth firms. This is also 
important for the tests examining future earnings, because the higher P/E ratio among the beaters suggests a higher expectation of growth in future earnings.

Panel B of Table 1 provides size-adjusted returns data for missers, meeters, and beaters. Consistent with prior research, firms that beat expectations outperform firms that miss expectations over all return horizons studied. However, we also find evidence that firms that exactly meet expectations are distinct from those that beat expectations. In terms of future performance, meeters resemble firms that missed their forecast. Meeters underperform beaters with the patterns remaining consistent over the next one, two and three years. This finding suggests that the tendency of prior research to group meeters and beaters together might be inappropriate, and that classifying these firms separately might provide a more accurate characterization. $^{9}$

To construct our earnings quality indicators, we use evidence from prior studies related to earnings quality and the availability of Compustat data. We begin with total accruals, which proxies for the relative permanence of a firm's earnings, and provides the basis for virtually all models of discretionary accruals. Total accruals are measured using the statement of cash flows, as the difference between net income and cash flow from continuing operations:

$$
A C C=N I-C F O
$$

where NI equals net income before extraordinary items (i.e. Compustat \#123) and $C F O$ equals cash flow from continuing operations (i.e. Compustat \#308 - Compustat\#124). ACC is divided by lagged total assets to control for scale differences. We do not use a discretionary accruals

\footnotetext{
${ }^{9}$ This is consistent with Baber and Kang (2002) who study the impact of split adjusting and rounding on analysts' forecast error calculations and find that firms that meet earnings forecasts (using unadjusted I/B/E/S data) have significantly negative 3 day abnormal returns. In contrast using adjusted I/B/E/S data results in earnings announcement returns that are significantly positive. They conclude that interpreting meeting expectations as good or bad news would depend on the extent to which the data is contaminated by split rounded observations.
} 
model, since results in Sloan (1996) and Xie (2001) suggest that total accruals perform equally well in predicting future performance.

We also need to obtain measures of cash based earnings management, which identify discretionary reduction in expenditures like $R \& D$ and advertising. Both the level of R\&D expense (Chan, Lakonishok and Sougiannis, 2001) and changes in R\&D expense (Chambers, Jennings and Thompson, 2002) have been shown to be related to future returns. However, since we are interested in firms adjusting expenditures in order to exceed the threshold, we examine scaled changes in R\&D and advertising as opposed to the level of these expenditures, using the following equations:

$$
\begin{aligned}
& \Delta R \& D=\left(R \& D_{t}-R \& D_{t-1}\right) / T A_{t-1} \\
& \Delta A d v=\left(A D V_{t}-A D V_{t-1}\right) / T A_{t-1}
\end{aligned}
$$

where $R \& D$ equals $R \& D$ expense, $A D V$ equals advertising expense, and $T A_{t-1}$ equals lagged total assets. We also carry out supplemental analyses using alternative expectation models for R\&D and advertising expense. First, we use Penman and Zhang’s (2002) Q-score methodology, which incorporates information on both the levels and changes in R\&D and advertising for the prior three years in their expectation model. Second, we use industry adjusted changes, which is calculated by subtracting the median change of the industry from the firm specific change. These alternative specifications yield similar results, so we use the relatively simpler measures defined in equations (2a) and (2b).

To account for the fact that managers are likely to substitute among the different methods depending on their circumstances, we also define an aggregate indicator of earnings quality that takes into account the effect of accruals, changes in R\&D, and changes in advertising. We create combined scores by integrating the three individual earnings quality signals using dichotomous 
variables for each of the individual variables that indicate whether the variable signals high or low quality earnings. For example, if a firm has a scaled change in R\&D (advertising) in excess of the median level of the scaled change in $R \& D$ (advertising) it receives a value of 1 , and 0 otherwise. Because low accruals indicate high quality earnings, firms with accruals below the median are coded as 1 and those above the median are coded as 0 . We then sum the variables to create an earnings quality statistic (EQSTAT). The maximum for EQSTAT is therefore 3 and the minimum is 0 . Firms with EQSTAT of 2 or3 are considered to have high quality earnings, while firms with an EQSTAT of 0 are considered to have low earnings quality. ${ }^{10}$

\section{Results}

Table 2 shows five-day returns surrounding the release of the earnings announcement, for firms falling above and below the median of our three individual earnings quality indicators: total accruals, changes in R\&D expense, and changes in advertising expense. We see a larger contemporaneous stock price reaction to firms beating analyst forecasts by one cent (i.e. the "1" group) relative to firms missing analyst forecasts by one cent (i.e. the “-1” group) within the full sample (difference $=0.90 \%$, $\mathrm{t}$-stat $=2.77$ ) as well as the $\mathrm{R} \& \mathrm{D}$ subsample $($ difference $=1.20 \%$, $\mathrm{t}$ stat=2.53). ${ }^{11}$ Consistent with research by Balsam, Bartov and Marquardt (2002), we see a larger price response to firms reporting low accruals relative to firms reporting high accruals at the earnings announcement date within the full sample (difference $=0.2 \%$, t-stat $=2.50$ ). Interestingly, for the R\&D sub-sample the difference is significant, but in the direction opposite to what would be predicted based on earnings quality. In particular, firms with below median

\footnotetext{
${ }^{10}$ Most firms in our sample do not have both advertising and R\&D expense. Therefore, we include values of 2 as high quality earnings, which typically means the firm has low accruals and above the median change in either R\&D or advertising.

${ }^{11}$ Because all firms in our sample are required to have accruals, the panel that includes both firms with high accruals and firms with low accruals contains all of the firms in our sample. The panels referring to R\&D, advertising, and earnings quality represent subsamples of the total sample.
} 
change in $R \& D$ are associated with significantly higher returns than firms with high $R \& D$ (difference $=-0.40 \%$, t-stat $=-2.44$ ). Part of this might be due to the fact that the level of R\&D might not be reported until the issuance of the 10-k, and the differential reaction at the earnings announcement date might capture the fact that high R\&D firms report lower net income and cash from operations, all else equal. The bottom two rows of Table 2 report the five day return for firms ranked on high and low earnings quality (EQSTAT). The results are similar as the results for the full sample, with firms that beat outperforming firms that miss by $1.3 \%$ (t-stat $=2.91$ ).

In the gray shaded cells, we highlight the differences between firms that beat earnings but have low quality earnings (either high accruals, below median changes in R\&D or below median changes in advertising) and firms that miss earnings but have high quality earnings. In all cases, firms that miss the forecast despite having high quality earnings underperform firms that beat the forecast but report low quality earnings, and the difference is significant for changes in R\&D, changes in advertising, and the aggregate earnings quality subsamples (t-stats of -4.42,-2.83, and -3.35 respectively).

Table 3 provides evidence about the future performance of firms when considering the interaction between the individual earnings quality indicators and meeting or beating expectations. Panel A provides the buy and hold return minus the buy and hold return of a portfolio consisting of all firms in the same size decile, extending to one year from the date of the earnings announcement. Panel B and Panel C provide evidence on cumulative two and three year returns. Our focus is on firms that beat expectations but do so by managing earnings upwards (i.e., low quality earnings) and firms that miss expectations but have high quality earnings (i.e. the off-diagonal cells). At the end of the one-year horizon (Panel A), we find that there are no significant differences between beaters with high accruals (low quality signal) and 
missers with low accruals (high quality signal), with a hedge portfolio generating $1.1 \%$.

However, at the two-year horizon (Panel B), the accrual effect begins to manifest with missers with low accruals outperforming beaters with high accruals (difference=3.5\%). This effect becomes stronger in the third year with three year cumulative hedge returns of $15.5 \%$. Using change in R\&D as our measure of the quality of earnings we find that missers with high quality signals underperform beaters with low quality signals in the first year (hedge returns of $-1.7 \%$ ). However, this reverses in the second and third year with incremental hedge returns of 3.9\% and $39.5 \%$ respectively. Our results using advertising run contrary to accruals and R\&D. In the case of advertising, our results suggest that firms that beat expectations but cut advertising expense outperform firms that miss expectations but continued spending on advertising over the threeyear horizon.

Examining the pattern of returns reveals that the effect of accruals and advertising are weaker at the three-year horizon, when compared with the effect of R\&D. In particular, the incremental returns for accrual and advertising based hedge portfolio returns in the third year are $12.0 \%$ and $-12.0 \%$ respectively. However, a hedge portfolio based on $R \& D$ generates an incremental abnormal return of approximately $36 \%$ in the third year. These findings are consistent with prior research, reflecting the notion that the effect of R\&D is likely to be felt over a longer horizon, while accruals and advertising have shorter horizon effects. ${ }^{12}$ Note that the magnitudes of these returns are likely overstated, because the only risk adjustment thus far is using a size-adjusted return. Analysis in the next section expands the risk adjustment to provide a more comprehensive list of potential risk factors.

\footnotetext{
${ }^{12}$ Bublitz and Ettredge (1989) and Hall (1992) suggest that advertising has a short useful life usually one to two years, while Sloan (1996) shows that the greatest impact from accruals comes one year after portfolio formation.
} 
It is also worth mentioning that firms that beat expectations and have high quality of earnings perform the best, and firms that miss expectations and have low quality of earnings signals perform the worst. For example, firms that miss their expectations despite having relatively high accruals underperform the market by $6.8 \%$, while firms that beat their expectations despite reporting low accruals enjoy the best returns, outperforming the market by $6.5 \%$ over the next year. A hedge portfolio of these two groups generates returns of $13.3 \%$ over a one-year horizon. The evidence using change in $R \& D$ is similar, with firms that miss expectations and have below median change in R\&D underperforming the market by $3.7 \%$ and firms beating expectations despite having high R\&D outperforming the market by $11.8 \%$. This results in a hedge portfolio return of $15.5 \%$ among a smaller subset of firms. Overall, these results demonstrate that while missing or beating expectations does provide some information about a firm's future prospects, integrating information about how the firm met its expectations increases the predictive ability of this measure.

To get a better sense of the overall effect of managing earnings through accruals or discretionary expenditures, Table 4 provides the results using the aggregate earnings quality statistic (EQSTAT). The integrated signal yields strong results, outperforming each of the individual signals. Once again, we can examine the off-diagonal cells to examine the relative performance of firms that exceed expectations by managing earnings and firms that miss expectations but did not manage earnings. By the end of the first year, there is no significant difference between firms that miss expectations but have high quality earnings and firms that beat expectations but have low quality earnings. However, by the end of the second year, the portfolio of high quality missers earns returns of $17.5 \%$ while the low quality beaters earn returns of $1.1 \%$ yielding a difference of $16.4 \%$. 
A potential concern with the results reported in Tables 3 and 4 is that the only risk control employed is size-adjusted returns, and there are no controls for explicit controls for other risk factors or industry profiles of the portfolios that we construct. To try to alleviate this concern, we use a cross-sectional regression design (e.g. Fama and Macbeth 1973) and include specific controls for known risk factors. Prior research and an unreported correlation matrix shows that accruals are correlated with size, book to market $(B / M)$, and price to earnings $(P / E)$ ratios, $\Delta R \& D$ is correlated with $B / M, P / E$, beta, and industry membership, and $\Delta A d v$ is correlated with industry membership. Consequently, our regressions include size, $B / M, P / E$, and beta as controls. A second concern is the effect of industry membership on future returns, in particular high tech industries and the bull market of the late 1990s. We account for this in two ways. First, we include industry fixed effects, using the industry classifications in Barth, Beaver, Hand and Landsman (1999). Second, we include an indicator variable for whether the firm is classified as a new economy firm (new_economy), using the classification in Murphy (2003). All nondichotomous variables are ranked, and then scaled to range from 0 to 1 , so that the coefficients can be interpreted as returns to a zero investment hedge portfolio. ${ }^{13}$ Coefficients and t-statistics are based on the time series average of the parameter estimates. Therefore, we estimate the following model:

$$
\begin{aligned}
& R_{i t}=\alpha+\beta_{1} * \text { miss }+\beta_{2}{ }^{*} \text { beat }+\beta_{3} * \text { lowE } Q+\beta_{4} * \text { highEQ }+\beta_{5} *(\text { miss } * l o w E Q)+ \\
& \left.\beta_{6} *(\text { miss } * \text { highEQ })+\beta_{7} * \text { (beat } * \text { low } E Q\right)+\beta_{8}^{*}(\text { beat } * \text { highEQ })+\beta_{9} * B / M \\
& +\beta_{10} * \text { Size }+\beta_{11} * \text { Beta }+\beta_{12} * P / E+\beta_{13} \text { new_economy }+\gamma_{k} \text { Industry Dummy } k+\varepsilon_{i t}
\end{aligned}
$$

Miss (beat) takes on a value of one if a firm has earnings per share that is exactly one cent below (above) the I/B/E/S consensus forecast issued during the second month of the firm's fourth

\footnotetext{
${ }^{13}$ Dichotomous variables do not need to be transformed, as the inclusion as a zero/one variable allows the coefficient to be interpreted as a hedge portfolio return.
} 
quarter, and zero otherwise. LowEQ (highEQ) takes on a value of one if the firm has a low (high) EQSTAT (earnings quality indicator) value and zero otherwise. Book-to-market ( $B / M)$, size, beta and price-to-earnings $(P / E)$ are included as their respective decile rank compared to other firms in the sample, scaled to range from a value of zero to one.

The coefficients for our two groups of interest (i.e., beaters with low earnings quality and missers with high earnings quality) are presented in columns one and two of Table 5. These coefficients are derived from equation (3), where the return to low quality beaters equals $\beta_{2}+\beta_{3}$ $+\beta_{7}$ and the return to high quality missers equals $\beta_{1}+\beta_{4}+\beta_{6}$. The results show that while industry and risk controls diminish the returns associated with these firms, the patterns remain consistent. Specifically, for most of the first 10 months following the earnings announcement, the low quality beaters significantly outperform the high quality missers. However, at one year they begin to equalize, and by month 25 , the high quality missers are significantly outperforming the low quality beaters. This pattern holds through the end of the three-year horizon. Thus, the earnings quality indicator captures information that is orthogonal to the information contained in size, beta, $B / M, P / E$, industry membership and whether the firm is classified as 'new economy'.

Figure 2 graphically displays the risk-adjusted cumulative monthly returns over the threeyear horizon for the high quality missers and low quality beaters to provide a better sense of the evolution of returns. For the first three quarters following the earnings announcement, the low quality beaters outperform the high quality missers, reflecting the premium associated with exceeding expectations. At about the one-year mark, the two portfolios are approximately equal, primarily from increased returns among the high quality missers. The two groups of firms stay approximately equal for another 4-5 months, after which they diverge dramatically. In particular, the high quality beaters increase substantially while the low quality beaters drift 
downward over the following two years. By the end of three years, the difference between the two groups of firms in substantial. Overall the results in Table 4 and Figure 2 show that firms that miss expectations but report high quality earnings eventually outperform firms that managed to beat expectations at the cost of reporting lower quality earnings. This suggests that investors should not place a premium on firms simply because they are able to beat expectations, but focus instead on the means by which they were able to do so. It also reveals the long-run negative consequences of myopic behavior, despite the short-run benefits, and suggests that managers who engage in this behavior likely have a preference for short term versus long term returns.

Our next table examines measures of earnings profitability to examine how the future earnings of these types of firms evolve over the long term. If our earnings quality indicators proxy for the relative permanence of earnings (or lack thereof), then we expect that the high quality earnings signals should be associated with greater increases in earnings than the firms with low quality earnings signals. Table 6 provides evidence on this by examining the change in ROA over the three years subsequent to the event year. ROA in the event year is defined as net income divided by beginning total assets. Future earnings changes are measured as the change in net income divided by total assets outstanding at the beginning of the first year. While this measure is similar to examining changes in ROA, it controls for the growth in assets resulting from the retention of net income by deflating with a constant denominator (see Fairfield, Whisenant, Yohn 2002). Examining the results in Table 6, the first difference is that firms that miss with high quality earnings report lower contemporaneous ROAs than firms that beat with low quality earnings ( $4.10 \%$ vs. $7.13 \%)$. This is not unexpected, since R\&D expense, advertising expense, and income-decreasing accruals all reduce net income, and by construction these firms fall into our high earnings quality category. Examining the performance in the 
following three years shows that the best future earnings performance comes from the high quality earnings category. High quality missers report economically significant positive earnings growth in the following three years while, in contrast, low earnings quality beaters exhibit significant negative changes in ROA in the year immediately following the report and insignificant changes thereafter. In all three years, the growth in profitability is significantly higher for the firms that missed expectations but reported high quality earnings (.59\%, 2.29\%, and $2.52 \%$ respectively). This is also interesting given that beaters have a higher P/E multiple relative to missers which would suggest that they have higher earnings growth expectations. In summary, this table provides further validation that the pattern we report in stock returns is related to fundamentals, and reflects the greater permanence of earnings in firms with high quality earnings signals.

Having examined the short and long run performance of firms that manage earnings to meet benchmarks, our final set of tests examines whether managers take advantage of the short term price benefit doing so. In particular we examine whether firms that beat with low quality earnings are more likely to issue equity or exhibit higher levels of insider selling in the following year. To examine equity issuance, we use the seasoned equity issuance data from Securities Data Corporation (SDC) database, and compute the frequency of equity issuances in the year following the earnings announcement using the issue date reported by SDC. We then use the following logistic model to examine the determinants of the equity issuance decision:

$$
\begin{aligned}
& \text { Issue }_{t, t+1}=\alpha+\beta_{1} \text { Beat_low }_{t}+\beta_{2} \text { Miss_low }_{t}+\beta_{3} \text { Beat_high }_{t}+\beta_{4} I s s u e_{t-2, t}+ \\
& \beta_{5} \text { Sales_growth }_{t-1, t}+\beta_{6} \text { Cash_ratio }_{t}+\beta_{7} \text { Return }_{t-1, t}+\beta_{8} \text { Adj_leverage }_{t}+\beta_{9} B / M_{t}+\varepsilon
\end{aligned}
$$

where Issue $t_{t,+1}$ is a dichotomous variable that equals one if the firm issues equity in the year following the earnings announcement, Beat_low $w_{t}$ is an indicator variable equal to 1 if the firm 
beats with low quality earnings, Miss_low is $_{t}$ an indicator variable if the firm misses forecasts with low quality earnings, and Beat high $h_{t}$ is an indicator variable equal to 1 if the firm beats forecasts with high quality earnings. The intercept captures the effect of a firm missing with high quality earnings. Thus, the coefficient $\beta_{l}$ captures the difference in equity issuance between the two primary groups of interest, Miss_high and Beat_low. Control variables are included to capture other factors that might influence the equity issuance decision. Issue $t_{t-2, t}$ is an indicator variable equal to 1 if the firm also issued equity in the past two years, to try to capture firms that have a tendency to obtain external financing through equity, Sales_growth measures the growth in sales over the past year in order to try to measure overall growth of the firm, Cash_ratio is the ratio of cash to total assets, to try to capture whether the firm has external financing needs, Return $_{t-1, \mathrm{t}}$ measures the market adjusted return over the past year to capture the fact that firms are more likely to issue when their stock price is relatively high (e.g. Dichev 2004), Adj_leverage is the industry-adjusted leverage of the firm which assumes that firms try to move towards an industry level capital structure, and $B / M$ is the book to market ratio, which is the inverse of the market to book ratio which captures future expected growth opportunities. ${ }^{14}$ Results of estimating this equation are presented in Table7.

The results in Table 7 suggest that among the control variables, past equity issuances, prior stock returns, and the book to market ratio are all statistically significant predictors of the equity issuance decision, while the other control variables are insignificant. More importantly, even after controlling for these factors, the fact that a firm beats with low quality earnings increases the likelihood that the firm will issue equity in the next year, relative to all other groups. Among our two primary groups of interest, firms that beat with low quality earnings are

\footnotetext{
${ }^{14}$ The book to market ratio is used instead of the market to book ratio because of the fact that the book value of equity can take on negative values.
} 
significantly more likely to issue equity than firms that miss with high quality earnings ( $\beta_{1}=$ 0.582, $\mathrm{p}=0.014$ ). One potential concern, however, is that the very act of beating (missing) suggests a firm will be more (less) likely to issue equity. However, firms that beat with low quality earnings are also significantly more likely to issue equity in the following year than firms that beat with high quality earnings $\left(\beta_{1}-\beta_{3}=0.463, \mathrm{p}=0.042\right)$. Thus, even among the subset of firms that beat expectations, it is the firms that appear to have the low quality earnings that are more likely to issue equity in the following year, which is consistent with their trading off long run earnings .

To examine insider selling, we use the Thomson’s insider transaction database to identify insider sales. Consistent with Richardson et al. (2004), insider transactions are defined as purchases or sales by the CEO, chair, officers, vice-presidents, and directors. Following Piotroski and Roulstone (2004), we define a measure of net insider selling (InsiderSales) that is defined as sales minus purchases, divided by the sum of shares purchases and sold. ${ }^{15}$ We measure InsiderSales for one year, starting three days after the earnings announcement. We then use the following regression model to determine whether insiders are more likely to sell when beating forecasts with low quality earnings:

$$
\begin{aligned}
& \text { InsiderSales } t, t+1_{t}=\alpha+\beta_{1} \text { Beat_low }_{t}+\beta_{2} \text { Miss_high }_{t}+\beta_{3} \text { Beat_high }_{t}+\beta_{4} \text { Return }_{t-1, t}+ \\
& \beta_{5} \text { Return_5day }_{t-1, t}+\beta_{6} \text { SalesGrowth }+\beta_{7} B / M_{t}+\gamma_{k} \text { Industry Dummy }_{k}+\delta_{j} \text { Year }_{j}+\varepsilon
\end{aligned}
$$

The variables Beat_low, Miss_high, and Beat_high $h_{t}$ are as defined before. Control variables include the previous year's stock return $\left(\right.$ Return $\left._{t-1, t}\right)$ and the five-day announcement period return (Return_5day $\left.{ }_{t-1, t}\right)$ to control for the fact that good performance will be associated with

\footnotetext{
${ }^{15}$ Note that we get qualitatively similar results if we use an unscaled measure of net insider sales (Total Sales Total Purchases) or the change in InsiderSales as the respective dependent variables.
} 
greater selling. Sales_growth is included to control for the fact that high growth firms are more likely to issue options and recent good stock price performance, and therefore might experience greater insider selling. $B / M$ and industry dummies are included to capture the fact that firms with high growth opportunities (low B/M ratios) and firms in certain industries are more likely to issue stock options as compensation. Year dummies are included to account for potential time clustering of insider sales. As before, $\beta_{l}$ measures the difference in net insider selling between the firms that beat with low quality earnings and firms that miss with high quality earnings, while $\beta_{I^{-}} \beta_{3}$ compares the insider selling between firms that beat expectation with low quality earnings and firms that beat expectations with high quality earnings. Results are presented in Table 8.

Consistent with the results in Table 7, Table 8 suggests that firms that beat expectations with low quality earnings have significantly greater insider sales than firms that that miss expectations with high quality earnings $\left(\beta_{1}=0.1078, \mathrm{p}=0.014\right)$. Firms that beat with low quality earnings are also significantly more likely to issue equity in the following year than firms that beat with high quality earnings $\left(\beta_{1}-\beta_{3}=0.088, p=0.046\right)$. Once again, it is not the fact that they beat expectations, but the interaction between beating and having low quality earnings that explains the significantly higher insider sales. With respect to the control variables, past returns and sales growth predict greater insider sales, while higher book to market ratios are associated with lower insider sales. Taken together, the results in Tables 7 and 8 suggest that firms that beat expectations by cutting discretionary expenditures or managing earnings are significantly more likely to issue equity and exhibit higher insider selling, consistent with managers of these firms taking advantage of the short term price support provided by beating expectations. 


\section{Conclusion}

Both investors and the financial press seem fixated on whether a firm exceeds or misses analysts’ expectations. Indeed, prior research and anecdotal evidence both suggest that a premium is placed on a firm's ability to beat this target and that there are often serious repercussions for missing this target. Recent experimental and survey evidence suggests that managers are willing to manage earnings and forego positive NPV projects to help maintain or increase stock price.

In this paper we examine the trade-off between the benefits derived from beating expectations and the costs incurred by using earnings management tools to achieve it. This paper shows that, while this strategy has short-term benefits, it has negative long-term effects. Specifically, we find that firms that use accruals or discretionary expenditures to beat a forecast enjoy a short-term positive impact on performance, but pay through a significant long-term underperformance relative to firms that missed expectations but had high quality earnings. Our results suggest that investors should pay particular attention to the quality of a firm's earnings when assessing the value relevance of a firm beating or missing expectations. For long-term investors it seems that a firm that misses expectations without managing earnings is better than a firm that beats expectations through earnings management.

We also examine whether managers behave in a manner that suggests they are cognizant of these tradeoffs. Specifically, we examine whether managers of firms that beat expectations through earnings management are more likely to take advantage of the positive short-run price impact. We find that these firms are more likely to issue stock and have greater insider selling. This findings hold when comparing these firms not only with firms that missed but also with firms that beat without managing earnings. 
Our findings also have implications for the earnings management literature. In particular, this paper shows that when determining quality of earnings, both accruals and cash expenditures should be considered. By creating indicators of earnings quality that take into account both factors, we develop a measure that is more predictive of future returns than any individual component. This suggests that these measures contain additional information that is relevant to overall earnings quality and future performance. Researchers who work on developing models of earnings management might consider incorporating cash-based measures in addition to accruals in order to develop more powerful models of managed earnings.

Finally, our results suggest that researchers should be careful when using the benchmark beating firms as a proxy for earnings management. We show that the set of companies that marginally beat analyst forecasts consists of firms with both high and low quality earnings, as does the set of firms that misses expectations. Consequently, inferring that firms manage earnings based on their likelihood to marginally exceed a benchmark omits additional information that would considerably improve the discriminating ability of this proxy. 


\section{References}

Baber, W. R., P. M. Fairfield, and J. A. Haggard. 1991. The Effect of Concern About Reported Income on Discretionary Spending Decisions - the Case of Research-and-Development. Accounting Review 66 (4):818-829.

Baber, W. R., and S. H. Kang. 2002. The Impact of Split Adjusting and Rounding on Analysts' Forecast Error Calculations. Accounting Horizons 16 (4): 277-289.

Balsam, S., E. Bartov, and C. Marquardt. 2002. Accruals management, investor sophistication, and equity valuation: Evidence from 10-Q filings. Journal of Accounting Research 40 (4):987-1012.

Bar-Gill, O. and L. Bebchuk. 2003. Misreporting Corporate Performance. Harvard University Working Paper.

Barth, M. E., J. A. Elliott, and M. W. Finn. Market rewards associated with patterns of increasing earnings. Journal of Accounting Research 37 (2):387.

Barth, M, B. Beaver, J. Hand and W. Landsman. 1999. Accruals, Cash Flows, and Equity Values. Review of Accounting Studies 4(3/4).

Bartov, E., D. Givoly, and C. Hayn. 2002. The rewards to meeting or beating earnings expectations. Journal of Accounting \& Economics 33 (2):173-204.

Bhojraj S. and Libby, R. 2004 “Capital Market Pressure, Disclosure Frequency-Induced Earnings/Cash Flow Conflicts, and Managerial Myopia” forthcoming in The Accounting Review (Jan 2005)

Brown, L. 2001. A Temporal Analysis of Earnings Surprises: Profits versus Losses. Journal of Accounting Research 39(2): 221-242.

Bublitz, B., and M. Ettredge. 1989. The Information in Discretionary Outlays - Advertising, Research, and Development. Accounting Review 64 (1):108-124.

Burgstahler, D. and M. Eames. 2002. Management of Earnings and Analysts' Forecasts to Achieve Zero and Small Positive Earnings Surprises, Working paper, Unviersity of Washington.

Chambers, D. J., R. Jennings and R. B. Thomson. 2002. Excess Returns to R\&D intensive firms.

Chan, L., J. Lakonishok, and T. Sougiannis, 2001. The Stock Market Valuation of R\&D Expenditures, Journal of Finance 8: 2431-2459.

Collins, D. W., and P. Hribar. 2000. Earnings-based and accrual-based market anomalies: one effect or two? Journal of Accounting \& Economics 29 (1):101-123. 
DeFond, M. L., and C. W. Park. 2001. The reversal of abnormal accruals and the market valuation of earnings surprises. Accounting Review 76 (3):375-404.

Degeorge, F., J. Patel, and R. Zeckhauser. 1999. Earnings management to exceed thresholds. The Journal of Business 72 (1):1.

Diether, K. B., C. J. Malloy, and A. Scherbina. 2002. Differences in opinion and the crosssection of stock returns. forthcoming, The Journal of Finance.

Fairfield, P. M., J. S. Whisenant, and T. L. Yohn. Accrued earnings and growth: Implications for future profitability and market mispricing. The Accounting Review 78 (1):353.

Fama, E. F., and J. D. Macbeth. 1973. Risk, Return, and Equilibrium - Empirical Tests. Journal of Political Economy 81 (3):607-636.

Graham, J. R., C. R. Harvey and S. Rajgopal. 2004. The economic implications of corporate financial reporting. Working paper Duke University and University of Washington.

Hayn, C. 1995. The Information-Content of Losses. Journal of Accounting \& Economics 20 (2):125-153.

Hribar, P. and D. Collins. 2002. Errors in Estimating Accruals: Implications for Empirical Research. Journal of Accounting Research 40(1).

Kasznik, R., and M. McNichols. 2002. Does Meeting Earnings Expectations Matter? Evidence from Analyst Forecast Revisions and Share Prices, Journal of Accounting Research 40(3): 727-759.

Loughran, T. and J. Ritter. 1995. The new issues puzzle. Journal of Finance 50(1):23-51.

Matsumoto, D. 2002. Management's Incentives to Avoid Negative Earnings Surprises, The Accounting Review 77(3): 483-514

Murphy, K. 2003. Stock Based Pay in New Economy Firms, Journal of Accounting and Economics forthcoming.

Payne, J. L., and S. G. Robb. Earnings management: The effect of ex ante earnings expectations. Journal of Accounting, Auditing \& Finance 15 (4):371.

Penman, S. H., and X. J. Zhang. 2002. Accounting conservatism, the quality of earnings, and stock returns. The Accounting Review 77 (2):237-264. 
Piotroski, J. and D. Roulstone. 2004. The influence of analysts, Institutional Investors, and Insiders on the Incorporation of Market, Industry, and Firm-Specific Information into Stock Prices. The Accounting Review 79(4): 1119-1151.

Rangan, S. 1998. Earnings around Seasoned Equity Offerings: Are they overstated? Journal of Financial Economics 50:100-121.

Richardson, S., S. Teoh, and P. Wysocki. 2004. The Walkdown to Beatable Analyst Forecasts: The Roles of Equity Issuance and Insider Trading Incentives. Contemporary Accounting Research pp. 885-924.

Skinner, D. and R. Sloan. 2002. Earnings Surprises, Growth Expectations, And Stock Returns, Or, Don’t Let An Earnings Torpedo Sink Your Portfolio. Review of Accounting Studies (7) $2 / 3$.

Sloan, R. 1996. Do Stock Prices Fully Reflect Information in Accruals and Cash Flows About Future Earnings? The Accounting Review 71(3): 289-315.

Spiess, K. and J. Affleck-Graves. 1995. Underperformance in long-run stock returns following seasoned equity offerings. Journal of Financial Economics 38:243-267.

Stein, J. 1989. Efficient Capital Markets, Inefficient Firms: A Model of Myopic Corporate Behavior. Quarterly Journal of Economics: 655-668.

Teoh, S, I. Welch, and T. Wong. 1998. Earnings Management and the Underperformance of Seasoned Equity Offerings. Journal of Financial Economics 50:63-99.

Xie, H. 2001. The Mispricing of Abnormal Accruals. The Accounting Review 76 (3): 357-373. 


\section{Table 1}

\section{Summary Statistics by earnings per share relative to consensus forecast}

Table values represent the equally-weighted average statistics for sample firms based on their earnings surprise in a given fiscal year. The earnings surprise is defined as the difference in cents between a firm's reported earnings per share for the given fiscal year and the I/B/E/S consensus forecast issued during the second month of the firm's fourth quarter. A firm whose earnings where within plus or minus half-a-cent of the consensus forecast would thus have an earnings surprise of zero, while a firm with reported earnings between half a cent and one-and-a-half cents above the consensus forecast would have an earning surprise of one, etc. All values in Panel A except beta are obtained using COMPUSTAT data for the given fiscal year. Total assets is COMPUSTAT item \#6, market value is shares outstanding (item \#25)*fiscal year closing stock price (item \#199), book to market is book value (item \#216) divided by market value, return on assets is net income (item \#18) divided by total assets, price to earnings is closing stock price divided by earnings per share (item \#58). Betas are calculated using the monthly returns for the firm over the past sixty months. The returns in Panel B are computed using CRSP returns data. The cumulative return for each individual firm is calculated and then adjusted by subtracting the cumulative market return of firms in the same CRSP size decile over the same period. Five-day returns are calculated as the cumulative return beginning two days before the earnings announcement and ending two days after the earnings announcement. All yearly returns are calculated without the five-day returns.

Panel A: Summary statistics by earnings position

\begin{tabular}{ccccccccc}
$\begin{array}{c}\text { Earnings } \\
\text { Surprise }\end{array}$ & Statistic & $\begin{array}{c}\text { Total } \\
\text { Assets }\end{array}$ & $\begin{array}{c}\text { Market } \\
\text { Value }\end{array}$ & $\begin{array}{c}\text { Book to } \\
\text { Market }\end{array}$ & $\begin{array}{c}\text { Return on } \\
\text { Assets }\end{array}$ & $\begin{array}{c}\text { Average } \\
\text { Beta }\end{array}$ & $\begin{array}{c}\text { Price to } \\
\text { Earnings }\end{array}$ & Obs. \\
\hline$<-1$ & Mean & $\mathbf{1 8 3 4 . 0}$ & $\mathbf{1 9 0 0 . 5}$ & $\mathbf{0 . 5 6}$ & $\mathbf{0 . 4 \%}$ & $\mathbf{1 . 0 8}$ & $\mathbf{1 8 . 4 4}$ & $\mathbf{1 3 , 4 8 7}$ \\
& Median & 247.3 & 243.3 & 0.49 & $3.7 \%$ & 1.05 & 14.25 & \\
-1 & & & & & & & & \\
& Mean & $\mathbf{1 8 1 4 . 3}$ & $\mathbf{2 7 0 3 . 8}$ & $\mathbf{0 . 4 4}$ & $\mathbf{4 . 6 \%}$ & $\mathbf{1 . 1 1}$ & $\mathbf{1 8 . 2 8}$ & $\mathbf{1 , 3 9 0}$ \\
& Median & 263.7 & 346.9 & 0.38 & $6.5 \%$ & 1.05 & 17.32 & \\
0 & & & & & & & & \\
& Mean & $\mathbf{1 4 5 7 . 0}$ & $\mathbf{3 1 2 8 . 0}$ & $\mathbf{0 . 4 3}$ & $\mathbf{6 . 3 \%}$ & $\mathbf{1 . 1 0}$ & $\mathbf{3 0 . 5 7}$ & $\mathbf{2 , 0 5 2}$ \\
& Median & 246.2 & 382.6 & 0.36 & $6.9 \%$ & 1.07 & 18.77 & \\
& & & & & & & & \\
& Mean & $\mathbf{1 2 7 7 . 0}$ & $\mathbf{2 4 2 0 . 0}$ & $\mathbf{0 . 4 0}$ & $\mathbf{6 . 1 \%}$ & $\mathbf{1 . 0 9}$ & $\mathbf{2 9 . 1 3}$ & $\mathbf{2 , 1 2 5}$ \\
& Median & 229.1 & 397.9 & 0.34 & $7.2 \%$ & 1.05 & 19.09 & \\
& & & & & & & & \\
& Mean & $\mathbf{1 8 8 9 . 9}$ & $\mathbf{2 8 0 9 . 1}$ & $\mathbf{0 . 4 5}$ & $\mathbf{4 . 3 \%}$ & $\mathbf{1 . 1 0}$ & $\mathbf{2 0 . 2 0}$ & $\mathbf{1 1 , 5 9 7}$ \\
& Median & 281.7 & 397.7 & 0.38 & $6.3 \%$ & 1.04 & 15.44 & \\
\hline
\end{tabular}

Panel B: Size Adjusted Returns for Firms having Analyst Data

\begin{tabular}{|c|c|c|c|c|c|}
\hline $\begin{array}{l}\text { Earnings } \\
\text { Position }\end{array}$ & $\begin{array}{l}\text { Number of } \\
\text { Observations }\end{array}$ & Five Day Returns & $\begin{array}{c}\text { One Year } \\
\text { Returns }\end{array}$ & $\begin{array}{c}\text { Cumulative } \\
\text { Two Year } \\
\text { Returns }\end{array}$ & $\begin{array}{c}\text { Cumulative } \\
\text { Three Year } \\
\text { Returns }\end{array}$ \\
\hline \multirow[t]{2}{*}{$<-1$} & Mean & $-0.6 \%$ & $-2.7 \%$ & $-2.1 \%$ & $-1.6 \%$ \\
\hline & Observations & 12,998 & 12,974 & 12,030 & 11,031 \\
\hline \multirow{2}{*}{-1} & Mean & $-0.3 \%$ & $-2.0 \%$ & $-2.5 \%$ & $1.1 \%$ \\
\hline & Observations & 1,367 & 1,364 & 1,239 & 1,121 \\
\hline \multirow[t]{2}{*}{0} & Mean & $0.0 \%$ & $0.7 \%$ & $4.8 \%$ & $0.0 \%$ \\
\hline & Observations & 2,019 & 2,017 & 1,834 & 1,625 \\
\hline \multirow[t]{2}{*}{1} & Mean & $0.6 \%$ & $4.1 \%$ & $7.2 \%$ & $7.2 \%$ \\
\hline & Observations & 2,099 & 2,095 & 1,893 & 1,669 \\
\hline \multirow[t]{2}{*}{$>1$} & Mean & $1.9 \%$ & $2.9 \%$ & $6.5 \%$ & $7.6 \%$ \\
\hline & Observations & 11,256 & 11,237 & 10,380 & 9,123 \\
\hline \multirow{2}{*}{ All Firms } & Mean & $0.0 \%$ & $0.2 \%$ & $2.3 \%$ & $2.6 \%$ \\
\hline & Observations & 29,739 & 29,687 & 27,376 & 24,569 \\
\hline
\end{tabular}




\section{Table 2}

\section{Five-day Abnormal returns surrounding the earnings announcement}

Table values are the size-adjusted returns for firms with high or low total accruals, change in R\&D, change in advertising, and high or low EQSTAT (earnings quality indicator) by earnings surprise category. The earnings surprise is defined as the difference in cents between a firm's reported earnings per share for the given fiscal year and the $\mathrm{I} / \mathrm{B} / \mathrm{E} / \mathrm{S}$ consensus forecast issued during the second month of the firm's fourth quarter. Firms are ranked as "high" in total accruals if the dollar amount of total accruals for a given fiscal year scaled by the firm's total assets is above the median level of total accruals scaled by total assets for all firms reporting accruals in the same fiscal year. Firms are ranked as high in change in R\&D and change in advertising if the change relative to the previous fiscal year in the dollar amount of the respective expenditure scaled by total assets is above the median level of change scaled by total assets for all firms reporting these expenditures in the same fiscal year. Firms are likewise ranked as "low" if the scaled level of the particular accounting variable is below the median of all firms for the same fiscal year. Firms that are missing total accruals, change in R\&D or change in advertising are not included in the returns calculations for the particular variable they are missing. EQSTAT is a ranking from zero to three with a firm receiving one point for each accounting variable, total accruals, change in $R \& D$, and change in advertising, each scaled by total assets, that is above (below for total accruals) the median level for all firms in a given year. No point is awarded for missing variables. A firm with a rank of three would thus have scaled total accruals below median and scaled change in R\&D and change in advertising above the median. "High" EQSTAT is defined as any firm with a rank of two or three. "Low" EQSTAT is defined as a firm with a rank of zero (no accounting variables on the favorable side of the median). The cumulative return for each individual firm over a particular time interval is calculated using daily CRSP returns and then adjusted by subtracting the cumulative market return of firms in the same CRSP size decile over the same period. Five day adjusted returns are calculated as the adjusted cumulative return beginning two days before the earnings announcement and ending two days after the earnings announcement. Reported returns are the equally weighted average of all size adjusted returns in a given earnings surprise-accounting variable category across all fiscal years in the sample (1988-2001). The ordering of high and low categories are different for accruals than for change in R\&D, change in advertising, and EQSTAT because low accruals represent high quality earnings while high change in R\&D, change in advertising, and EQSTAT represent high quality earnings.

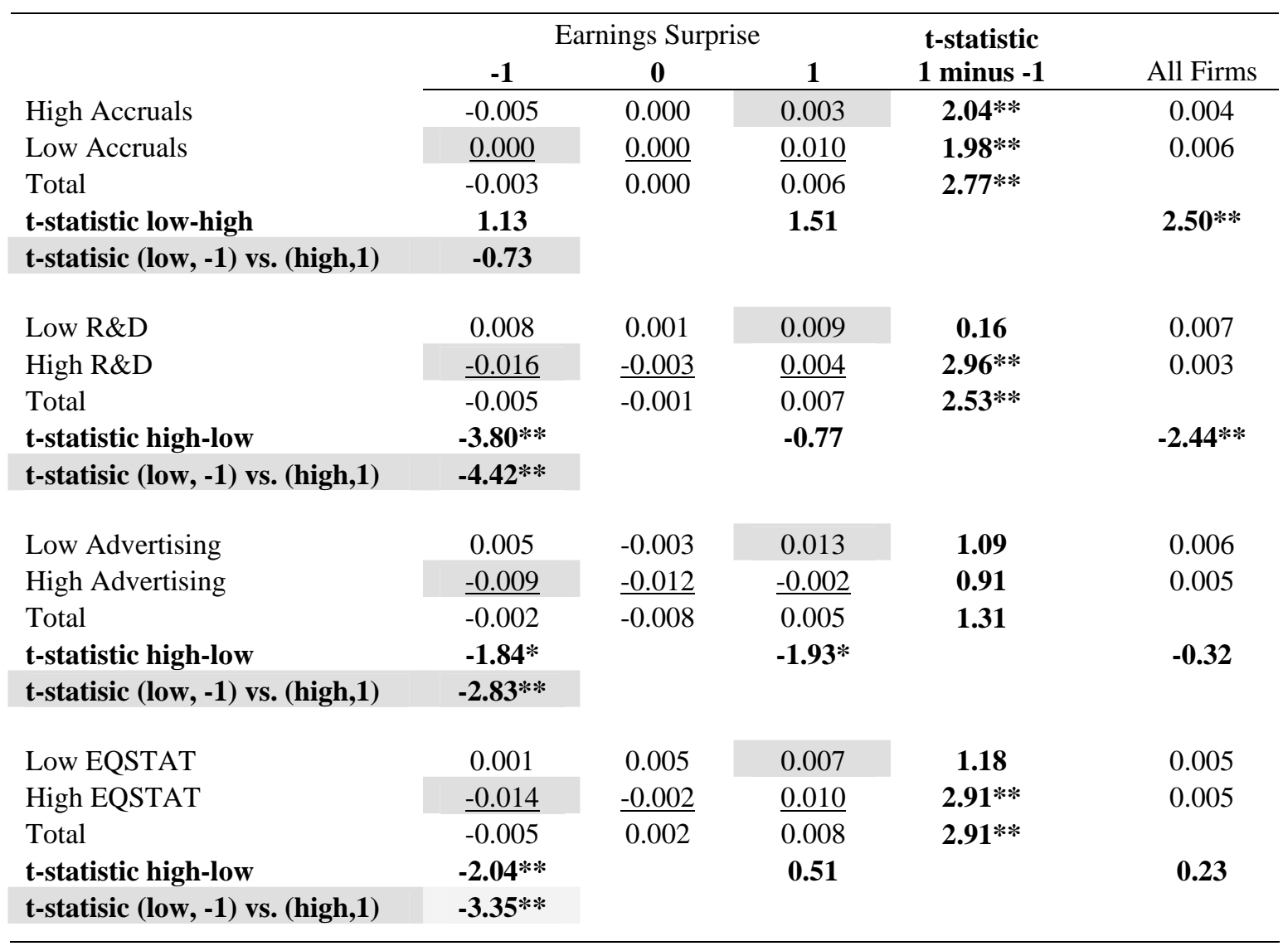

* denotes significance at a probability of $<.10$, ${ }^{* *}$ denotes significance at a probability of $<.05$, two-tailed tests. 


\section{Table 3}

\section{Future size adjusted returns by earnings position for total accruals, $R \& D$ and advertising}

Table values show the size adjusted returns for firms with high or low total accruals, change in R\&D or change in advertising by earnings surprise. The earnings surprise is defined as the difference in cents between a firm's reported earnings per share for the given fiscal year and the I/B/E/S consensus forecast issued during the second month of the firm's fourth quarter. Firms are ranked as "high" in total accruals if the dollar amount of total accruals for a given fiscal year scaled by the firm's total assets is above the median level of total accruals scaled by total assets for all firms reporting accruals in the same fiscal year. Firms are ranked as high in change in R\&D and change in advertising if the change relative to the previous fiscal year in the dollar amount of the respective expenditure scaled by total assets is above the median level of change scaled by total assets for all firms reporting these expenditures in the same fiscal year. Firms are likewise ranked as "low" if the scaled level of the particular accounting variable is below the median of all firms for the same fiscal year. Firms that are missing total accruals, change in R\&D or change in advertising are not included in the returns calculations for the particular variable they are missing. The cumulative return for each individual firm over a particular time interval is calculated using daily CRSP returns and then adjusted by subtracting the cumulative market return of firms in the same CRSP size decile over the same period. Five day adjusted returns are calculated as the adjusted cumulative return beginning two days before the earnings announcement and ending two days after the earnings announcement. All yearly cumulative returns are calculated without the five day returns. Reported returns are the equally weighted average of all size adjusted returns in a given earnings surprise-accounting variable category across all fiscal years in the sample (1988-2001).

\section{Panel A: One Year Size Adjusted Returns by Position for Total Accruals, Change in R\&D, and Change in Advertising}

\section{Total Accruals}

Earnings Position

high

\begin{tabular}{|c|c|c|c|}
\hline-1 & 0 & 1 & \\
\hline-0.068 & -0.021 & 0.022 & -0.016 \\
\hline 0.033 & 0.044 & 0.065 & \begin{tabular}{|l|l}
0.049 \\
\end{tabular} \\
\hline-0.021 & 0.007 & 0.041 & \\
\hline
\end{tabular}

\section{$\triangle \mathbf{R} \& \mathbf{D}$}

Earnings Position

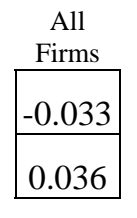

low

high

\begin{tabular}{c|c|c|c}
\multicolumn{1}{c|}{0} & \multicolumn{1}{c}{1} & \multicolumn{1}{c}{0} \\
\hline-0.037 & 0.020 & 0.022 & 0.007 \\
\hline 0.005 & 0.000 & 0.118 & 0.047 \\
\hline-0.015 & 0.010 & 0.072 &
\end{tabular}

\section{$\Delta$ Advertising}

Earnings Position

\begin{tabular}{|c|c|c|c|c|c|}
\hline & & & & & \\
\hline Firms & & -1 & 0 & 1 & \\
\hline-0.006 & low & 0.037 & 0.027 & 0.088 & 0.052 \\
\hline 0.037 & high & -0.083 & -0.049 & 0.018 & -0.032 \\
\hline & & -0.022 & -0.013 & 0.051 & \\
\hline
\end{tabular}

All

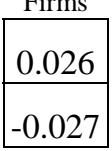

$-0.027$

Earnings Position

Earnings Position

All

\begin{tabular}{|l|}
\hline Firms \\
\hline-0.022 \\
\hline 0.068 \\
\hline
\end{tabular} low

\begin{tabular}{|c|c|c|c}
\multicolumn{1}{c|}{-1} & 0 & 1 & \multirow{2}{*}{0.005} \\
\hline-0.084 & -0.003 & 0.042 & -0.005 \\
\hline 0.081 & 0.125 & 0.228 & 0.154 \\
\cline { 1 - 3 } 0.001 & 0.063 & 0.139 &
\end{tabular}

All \begin{tabular}{|c|} 
Firms \\
\hline-0.014 \\
\hline 0.137 \\
\hline
\end{tabular} low

high
All 
Table 3 (Continued)

Panel C: Three Year Size Adjusted Returns by Position for Total Accruals, Change in R\&D, and Change in Advertising Total Accruals

Earnings Position

\begin{tabular}{|c|c|c|c|c|}
\hline \multirow[b]{2}{*}{ high } & -1 & 0 & 1 & \multirow[b]{2}{*}{-0.051} \\
\hline & -0.127 & -0.073 & 0.019 & \\
\hline low & 0.174 & 0.098 & 0.143 & 0.135 \\
\hline & 0.012 & 0.000 & 0.072 & \\
\hline
\end{tabular}

\section{$\triangle \mathbf{R} \& \mathbf{D}$}

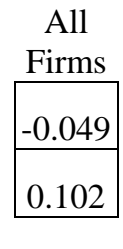

Earnings Position

\begin{tabular}{|c|c|c|c|c|}
\hline & \multicolumn{3}{|c|}{ Earnings Position } & \multirow[b]{3}{*}{-0.066} \\
\hline & -1 & 0 & 1 & \\
\hline low & -0.163 & -0.025 & -0.042 & \\
\hline high & 0.353 & 0.095 & 0.350 & 0.256 \\
\hline & 0.113 & 0.039 & 0.162 & \\
\hline
\end{tabular}

\section{$\Delta$ Advertising}

Earnings Position

All
Firms
\begin{tabular}{|c|}
\hline-0.027 \\
\hline 0.219 \\
\hline
\end{tabular}

All

\begin{tabular}{|c|c|c|c}
\hline-1 & 0 & 1 \\
\hline 0.062 & 0.093 & 0.231 & 0.134 \\
\hline-0.005 & -0.090 & 0.095 & 0.001 \\
\cline { 1 - 3 } 0.029 & -0.006 & 0.158 &
\end{tabular}




\section{Table 4}

\section{Size adjusted returns by earnings position for aggregate earnings quality signals}

Table values show the size-adjusted returns for firms with high or low EQSTAT (earnings quality indicator) values by earnings surprise category. The earnings surprise is defined as the difference in cents between a firm's reported earnings per share for the given fiscal year and the I/B/E/S consensus forecast issued during the second month of the firm's fourth quarter. EQSTAT is a ranking from zero to three with a firm receiving one point for each accounting variable, total accruals, change in R\&D, and change in advertising, each scaled by total assets, that is above (below for total accruals) the median level for all firms in a given year. No point is awarded for missing variables. A firm with a rank of three would thus have scaled total accruals below median and scaled change in R\&D and change in advertising above the median. "High" EQSTAT is defined as any firm with a rank of two or three. "Low" EQSTAT is defined as a firm with a rank of zero (no accounting variables on the favorable side of the median). The cumulative return for each individual firm over a particular time interval is calculated using daily CRSP returns and then adjusted by subtracting the cumulative market return of firms in the same CRSP size decile over the same period. Five day adjusted returns are calculated as the adjusted cumulative return beginning two days before the earnings announcement and ending two days after the earnings announcement. All yearly cumulative returns are calculated without the five day returns. Reported returns are the equally weighted average of all size adjusted returns in a given earnings surprisesummary variable category across all fiscal years in the sample (1988-2000).

\section{Panel A: One Year Size Adjusted Returns by Position and EQSTAT}

\begin{tabular}{l|c|c|c|c}
\multicolumn{5}{c}{ Earnings Relative to Forecast } \\
\cline { 3 - 4 } low & -1 & 0 & 1 & \multirow{2}{*}{0.021} \\
\cline { 2 - 4 } high & -0.080 & -0.022 & 0.015 & 0.056 \\
\cline { 2 - 4 } & 0.009 & 0.001 & 0.134 & 0.056 \\
\cline { 2 - 4 } & -0.045 & -0.014 & 0.060 &
\end{tabular}

Panel B: Two Year Cumulative Size Adjusted Returns by Position and EQSTAT

\begin{tabular}{l|c|c|c|c}
\multicolumn{5}{c}{ Earnings Relative to Forecast } \\
\cline { 3 - 4 } low & -1 & 0 & 1 & \multirow{2}{*}{-0.035} \\
\cline { 2 - 4 } high & -0.125 & -0.030 & 0.011 & 0.187 \\
\cline { 2 - 4 } & 0.175 & 0.092 & 0.281 & \\
\cline { 2 - 4 } & -0.009 & 0.014 & 0.112 &
\end{tabular}

Panel C: Three Year Cumulative Size Adjusted Returns by Position and EQSTAT

\begin{tabular}{l|c|c|c|c}
\multicolumn{5}{c}{ Earnings Relative to Forecast } \\
\cline { 3 - 4 } low & -1 & 0 & 1 & \multirow{2}{*}{-0.123} \\
\cline { 2 - 4 } high & -0.232 & -0.115 & -0.069 & 0.300 \\
\cline { 2 - 4 } & 0.481 & 0.101 & 0.376 & 0.095
\end{tabular}




\section{Table 5}

\section{Monthly regressions of earnings quality and earnings surprise on future returns}

Table 5 shows the results of regressions of monthly future size adjusted cumulative returns on earnings quality and earnings surprise category. Results are shown for one month following a firm's earning announcement until thirty-six months after the announcement. The regression is run on all future monthly returns for fiscal years 1988-2001 and takes the form:

$R_{i t}=\alpha+\beta_{1} *$ miss $+\beta_{2} *$ beat $+\beta_{3} *$ low $E Q+\beta_{4} *$ highEQ $+\beta_{5} *($ miss $*$ low $E Q)+\beta_{6} *($ miss $*$ highEQ $)+\beta_{7} *$ (beat $*$ low $\left.E Q\right)$

$+\beta_{8} *($ beat $*$ highEQ $)+\beta_{9} * B / M+\beta_{10} *$ Size $+\beta_{11} *$ Beta $+\beta_{12} * P / E+\beta_{13}$ new_economy + Industry Dummies $+\varepsilon_{i t}$

$\mathrm{R}_{\mathrm{it}}$ is the cumulative return $\mathrm{t}$ months after the release of firm i's annual report. Earnings surprise, earnings quality and the other regressors are derived from the current annual report and are used for all thirty-six monthly regressions. Miss, beat, lowEQ and highEQ are all binary variables. Miss (beat) takes on a value of one if a firm has earnings per share that are exactly one cents below (above) the I/B/E/S consensus forecast issued during the second month of the firm's fourth quarter (i.e. half-a-cent to one-and-a-half cents below (above) forecast), and zero otherwise. LowEQ (highEQ) takes on a value of one if the firm has a low (high) EQSTAT (earnings quality indicator) value and zero otherwise. Book-to-market, size, Beta and price-to-earnings are included as their respective decile rank compared to the other firms in the sample, scaled to range from a value of zero to one. Twelve industry dummies based on firm's 4-digit SIC codes are also included in the regression to control for industry effects. The coefficients for the earnings surprise-earnings quality groups of interest, beat by one cent with low earnings quality and miss by one cent with high earnings quality, are presented in columns one and two of the table. These coefficients are derived as follows:

Beat $/$ Low $=\beta_{2}+\beta_{3}+\beta_{7} \quad$ (beat $+\operatorname{low} E Q+$ beat $*$ low $\left.E Q\right)$

Miss/High $=\beta_{1}+\beta_{4}+\beta_{6}$ (miss + highEQ + miss $*$ highEQ $)$

Columns three and four show the difference in these coefficients and the t-statistic for a two-tailed test to determine whether this difference is significantly different from zero. Columns five through eight show the values and significance of the coefficients for book-to-market, size, Beta and price-to-earnings. The cumulative return for each individual firm over a particular time interval is calculated using daily CRSP returns and then adjusted by subtracting the cumulative market return of firms in the same CRSP size decile over the same period.

\begin{tabular}{ccccccccc}
\hline Month & Beat/Low & Miss/High & Difference & t-stat & B/M & Size & Beta & P/E \\
\hline 1 & -0.001 & -0.039 & 0.038 & $\mathbf{3 . 1 2} 2^{* *}$ & $0.018^{* *}$ & $0.008^{* *}$ & 0.000 & $0.005^{*}$ \\
2 & -0.007 & -0.045 & 0.037 & $\mathbf{2 . 3 2} 2^{* *}$ & $0.030^{* *}$ & 0.004 & $-0.010^{*}$ & $0.018^{* *}$ \\
3 & -0.014 & -0.022 & 0.009 & $\mathbf{0 . 4 5}$ & $0.058^{* *}$ & 0.005 & -0.009 & $0.033^{* *}$ \\
4 & -0.005 & -0.024 & 0.018 & $\mathbf{0 . 8 0}$ & $0.064^{* *}$ & 0.009 & $-0.012^{*}$ & $0.044^{* *}$ \\
5 & 0.006 & -0.033 & 0.039 & $\mathbf{1 . 5 0}$ & $0.051^{* *}$ & -0.005 & $-0.02^{* *}$ & $0.045^{* *}$ \\
6 & -0.007 & -0.057 & 0.050 & $\mathbf{1 . 7 3} *$ & $0.064^{* *}$ & -0.004 & $-0.023^{* *}$ & $0.054^{* *}$ \\
7 & -0.005 & -0.071 & 0.066 & $\mathbf{2 . 0 8} *$ & $0.068^{* *}$ & -0.007 & $-0.027^{* *}$ & $0.068^{* *}$ \\
8 & 0.008 & -0.072 & 0.080 & $\mathbf{2 . 3 2} 2^{* *}$ & $0.061^{* *}$ & $-0.017^{*}$ & $-0.037^{* *}$ & $0.068^{* *}$ \\
9 & 0.018 & -0.056 & 0.074 & $\mathbf{1 . 9 8} 8^{* *}$ & $0.059^{* *}$ & $-0.024^{* *}$ & $-0.034^{* *}$ & $0.069^{* *}$ \\
10 & 0.022 & -0.050 & 0.072 & $\mathbf{1 . 8 4} *$ & $0.065^{* *}$ & $-0.027^{* *}$ & $-0.039^{* *}$ & $0.069^{* *}$ \\
11 & 0.035 & -0.031 & 0.066 & $\mathbf{1 . 4 3}$ & $0.064^{* *}$ & $-0.029^{* *}$ & $-0.030^{* *}$ & $0.060^{* *}$ \\
12 & 0.007 & -0.016 & 0.024 & $\mathbf{0 . 4 4}$ & $0.071^{* *}$ & $-0.029^{*}$ & -0.021 & $0.041^{* *}$ \\
13 & 0.007 & 0.015 & -0.008 & $\mathbf{- 0 . 1 4}$ & $0.077^{* *}$ & -0.024 & 0.023 & $0.028^{*}$ \\
14 & 0.018 & 0.017 & 0.001 & $\mathbf{0 . 0 2}$ & $0.094^{* *}$ & -0.025 & 0.005 & $0.035^{* *}$ \\
15 & 0.023 & 0.008 & 0.015 & $\mathbf{0 . 2 4}$ & $0.123^{* *}$ & -0.023 & 0.006 & $0.044^{* *}$ \\
16 & 0.008 & 0.003 & 0.005 & $\mathbf{0 . 0 7}$ & $0.132^{* *}$ & -0.024 & 0.016 & $0.048^{* *}$ \\
17 & 0.007 & 0.043 & -0.036 & $\mathbf{- 0 . 4 6}$ & $0.116^{* *}$ & $-0.045^{* *}$ & 0.014 & $0.040^{* *}$ \\
18 & -0.005 & 0.092 & -0.097 & $\mathbf{- 1 . 1 9}$ & $0.131^{* *}$ & $-0.050^{* *}$ & 0.009 & $0.040^{*}$ \\
19 & -0.006 & 0.095 & -0.101 & $\mathbf{- 1 . 1 0}$ & $0.123^{* *}$ & $-0.066^{* *}$ & 0.011 & 0.030 \\
20 & -0.006 & 0.085 & -0.091 & $\mathbf{- 1 . 0 9}$ & $0.131^{* *}$ & $-0.057^{* *}$ & 0.005 & $0.049^{* *}$
\end{tabular}


Table 5 (Continued)

\begin{tabular}{|c|c|c|c|c|c|c|c|c|}
\hline Month & Beat/Low & Miss/High & Difference & t-stat & $\mathrm{B} / \mathrm{M}$ & Size & Beta & $\mathrm{P} / \mathrm{E}$ \\
\hline 21 & -0.018 & 0.088 & -0.106 & -1.30 & $0.127^{* *}$ & $-0.047 * *$ & 0.003 & $0.051^{* *}$ \\
\hline 22 & -0.003 & 0.091 & -0.094 & -1.09 & $0.126^{* *}$ & $-0.056^{* *}$ & -0.011 & $0.043^{*}$ \\
\hline 23 & -0.045 & 0.069 & -0.114 & -1.02 & $0.122^{* *}$ & $-0.052 * *$ & -0.019 & 0.037 \\
\hline 24 & -0.057 & 0.075 & -0.132 & -1.43 & $0.140^{* *}$ & $-0.051^{*}$ & 0.008 & 0.027 \\
\hline 25 & -0.080 & 0.091 & -0.171 & $-2.44 * *$ & 0.025 & $-0.071 * *$ & $0.084 * *$ & -0.047 \\
\hline 26 & -0.079 & 0.091 & -0.171 & $-2.40 * *$ & $0.059^{*}$ & $-0.075 * *$ & $0.077^{* *}$ & -0.035 \\
\hline 27 & -0.087 & 0.089 & -0.175 & $-2.39 * *$ & $0.086^{* *}$ & $-0.062 *$ & $0.090^{* *}$ & -0.029 \\
\hline 28 & -0.101 & 0.102 & -0.203 & $-2.77 * *$ & $0.084^{* *}$ & $-0.065^{*}$ & $0.095^{* *}$ & -0.034 \\
\hline 29 & -0.092 & 0.091 & -0.183 & $-2.37 * *$ & $0.069^{*}$ & $-0.083 * *$ & $0.097 * *$ & -0.026 \\
\hline 30 & -0.091 & 0.094 & -0.185 & $-2.36^{* *}$ & $0.083^{* *}$ & $-0.089 * *$ & $0.112^{* *}$ & -0.015 \\
\hline 31 & -0.095 & 0.097 & -0.192 & $-2.40 * *$ & $0.090^{* *}$ & $-0.083^{* *}$ & $0.119 * *$ & -0.008 \\
\hline 32 & -0.090 & 0.101 & -0.192 & $-2.38 * *$ & $0.093^{* *}$ & $-0.073^{* *}$ & $0.111^{* *}$ & -0.003 \\
\hline 33 & -0.098 & 0.097 & -0.195 & $-2.35^{* *}$ & $0.090^{* *}$ & $-0.085^{* *}$ & $0.097 * *$ & 0.004 \\
\hline 34 & -0.100 & 0.096 & -0.196 & $-2.29 * *$ & $0.085^{* *}$ & $-0.092 * *$ & $0.083^{* *}$ & 0.009 \\
\hline 35 & -0.097 & 0.124 & -0.221 & $-2.54 * *$ & $0.092^{* *}$ & $-0.075^{*}$ & 0.052 & 0.009 \\
\hline 36 & -0.107 & 0.109 & -0.217 & $-2.43^{* *}$ & $0.111^{* *}$ & -0.053 & 0.069 & -0.008 \\
\hline
\end{tabular}

* denotes significance at a probability of $<.10$, ** denotes significance at a probability of $<.05$, two-tailed tests. 


\section{Table 6 \\ Future change in return on assets by earnings position for aggregate earnings quality indicator}

Table 6 shows the future change in ROA values over the next three years for firms with high or low earnings quality by earnings surprise category. ROA is measured as net income divided by beginning of period total assets. The earnings surprise is defined as the difference in cents between a firm's reported earnings per share for the given fiscal year and the I/B/E/S consensus forecast issued during the second month of the firm's fourth quarter. "Miss" implies that earnings were one cent below expectations; "beat" implies that earnings were one cent above expectations.

Earnings quality is measured using EQSTAT. EQSTAT is a ranking from zero to three with a firm receiving one point for each accounting variable, total accruals, change in R\&D, and change in advertising, each scaled by total assets, that is above (below for total accruals) the median level for all firms in a given year. No point is awarded for missing variables. A firm with a rank of three would thus have scaled total accruals below median and scaled change in R\&D and change in advertising above the median. "High" EQSTAT is defined as any firm with a rank of two or three. "Low" EQSTAT is defined as a firm with a rank of zero (no accounting variables on the favorable side of the median). Firms with ROA's in the top or bottom $1 \%$ in each period and firms with assets below ten million dollars are eliminated in order to reduce variance.

\begin{tabular}{rcccc}
\hline & $\mathrm{ROA}_{\mathrm{t}}$ & $\begin{array}{c}\mathrm{NI}_{\mathrm{t}+1}-\mathrm{NI}_{\mathrm{t}} / \\
\text { Assets }_{\mathrm{t}-1}\end{array}$ & $\begin{array}{c}\mathrm{NI}_{\mathrm{t}+2}-\mathrm{NI}_{\mathrm{t}+1} / \\
\text { Assets }_{\mathrm{t}-1}\end{array}$ & $\begin{array}{c}\mathrm{NI}_{\mathrm{t}+3}-\mathrm{NI}_{\mathrm{t}+2} / \\
\text { Assets }_{\mathrm{t}-1}\end{array}$ \\
\hline Beat; low earnings quality & 0.0713 & $-0.0063^{*}$ & 0.0014 & 0.008 \\
Miss; high earnings quality & 0.0410 & -0.0004 & $0.0243^{* *}$ & $0.0332^{* *}$ \\
Difference & $-0.0303^{* *}$ & $0.0059^{*}$ & $0.0229 * *$ & $0.0252^{* *}$ \\
\hline
\end{tabular}

$*$ denotes significance at a probability of $<.10, * *$ denotes significance at a probability of $<.05$, two-tailed tests. 


\section{Table 7.}

\section{Determinants of seasoned equity offerings the year following the earnings announcement.}

This table models the likelihood of issuing equity in the year following the earnings announcement using a logistic

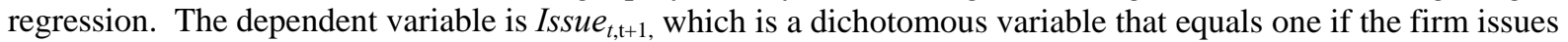
equity in the year following the earnings announcement, and zero otherwise. Miss_high $h_{t}$ is an indicator variable if the firm misses forecasts with high quality earnings, Beat_low $w_{t}$ is an indicator variable equal to 1 if the firm beats with low quality earnings, Beat_high $h_{t}$ is an indicator variable equal to 1 if the firm beats forecasts with high quality earnings. Issue $e_{t-2, t}$ is an indicator variable equal to 1 if the firm also issued equity in the past two years, to try to capture firms that have a tendency to obtain external financing through equity, Sales_growth measures the growth in sales over the past year in order to try to measure overall growth of the firm, Cash_ratio is the ratio of cash to total assets, to try to capture whether the firm has external financing needs, Return $_{t-1, \mathrm{t}}$ measures the market adjusted return over the past year to capture the fact that firms are more likely to issue when their stock price is relatively high (e.g. Dichev 2004), Adj_leverage is the industry-adjusted leverage of the firm which assumes that firms try to move towards an industry level capital structure, and $B / M$ is the book to market ratio, which is the inverse of the market to book ratio which captures future expected growth opportunities. The sample consists of all firms that missed or beat analyst consensus forecasts by one cent over the years 1988-2001.

\begin{tabular}{|c|c|c|c|c|c|}
\hline Variable & $\begin{array}{c}\text { Pred. } \\
\text { Sign }\end{array}$ & Estimate & $\begin{array}{c}\text { Standard } \\
\text { Error }\end{array}$ & $\begin{array}{l}\text { Wald Chi } \\
\text { Square }\end{array}$ & $\begin{array}{l}\text { Prob }>\text { Chi } \\
\text { Square }\end{array}$ \\
\hline Intercept & & -2.552 & 0.272 & 88.396 & $<.0001$ \\
\hline Beat_low ${ }_{t}$ & + & 0.582 & 0.237 & 6.017 & 0.0142 \\
\hline Miss_low & $?$ & -0.017 & 0.309 & 0.003 & 0.9558 \\
\hline Beat_high $_{t}$ & $?$ & 0.119 & 0.283 & 0.178 & 0.6733 \\
\hline Issue $_{t-2, t}$ & + & 0.842 & 0.195 & 18.593 & $<.0001$ \\
\hline Sales Growth & + & 0.022 & 0.077 & 0.082 & 0.7743 \\
\hline Cash Ratio $_{t-1}$ & - & -0.524 & 0.429 & 1.491 & 0.222 \\
\hline Return $_{\mathrm{t}-1}$ & + & 0.547 & 0.126 & 18.965 & $<.0001$ \\
\hline Adjusted Leverage $_{\mathrm{t}-1}$ & + & -0.010 & 0.383 & 0.001 & 0.9789 \\
\hline Book to Market $_{t}$ & - & -1.070 & 0.372 & 8.291 & 0.004 \\
\hline \multicolumn{6}{|c|}{$\begin{array}{l}\text { Goodness of Fit Model Chi-Square statistic: } 80.43(\mathrm{df}=9) \text {; Prob Chi Square }>80.43, \mathrm{p}<0.0001 \\
\text { Number of observations = } 1872\end{array}$} \\
\hline \multicolumn{6}{|c|}{$\begin{array}{l}\text { Test: } \text { Beat_low }=\text { Miss_high }: \text { estimate }=0.582 \text {, Prob }>\text { Chi-Square }=0.014 . \\
\text { Test: Beat_low }=\text { Beat_high }: \text { estimate }=0.463, \text { Prob }>\text { Chi-square }=0.042 .\end{array}$} \\
\hline
\end{tabular}


Table 8.

Determinants of net insider sales the year following the earnings announcement.

This table models the net insider sales in the year following the earnings announcement using ordinary least squares. The dependent variable is InsiderSales $s_{t, \mathrm{t}+1}$, which is equal to total sales - total purchases divided by total sales plus purchases, in the year following the earnings announcement, Miss_high $h_{t}$ is an indicator variable if the firm misses forecasts with high quality earnings, Beat_low $w_{t}$ is an indicator variable equal to 1 if the firm beats with low quality earnings, Beat_high $h_{t}$ is an indicator variable equal to 1 if the firm beats forecasts with high quality earnings. Issue $e_{t-2, t}$ is an indicator variable equal to 1 if the firm also issued equity in the past two years, to try to capture firms that have a tendency to obtain external financing through equity, Sales_growth measures the growth in sales over the past year in order to try to measure overall growth of the firm, Return $_{t-1, \mathrm{t}}$ measures the market adjusted return over the past year to capture the fact that insiders are more likely to sell when their stock price is relatively high, Ret_5day is the five-day market adjusted return surrounding the earnings announcement, and $B / M$ is the book to market ratio, which is the inverse of the market to book ratio which captures future expected growth opportunities. Industry dummies and year dummies are included as fixed effects. The sample consists of all firms that missed or beat analyst consensus forecasts by one cent over the years 1988-2001.

\begin{tabular}{|c|c|c|c|c|c|}
\hline Variable & $\begin{array}{l}\text { Pred. } \\
\text { Sign }\end{array}$ & Estimate & $\begin{array}{l}\text { Standard } \\
\text { Error }\end{array}$ & t-stat & p-value \\
\hline Intercept & & -0.0594 & 0.052 & -1.15 & 0.710 \\
\hline Beat_low ${ }_{t}$ & + & 0.1078 & 0.044 & 2.45 & 0.014 \\
\hline Miss_low & ? & 0.0439 & 0.044 & 0.90 & 0.407 \\
\hline Beat_high $_{t}$ & ? & 0.0193 & 0.047 & 0.40 & 0.455 \\
\hline Return $_{\mathrm{t}-1, \mathrm{t}}$ & + & 0.0543 & 0.024 & 2.28 & 0.023 \\
\hline Ret_5day & + & 0.1680 & 0.143 & 1.18 & 0.024 \\
\hline Sales Growth $\mathrm{t}_{\mathrm{t}-\mathrm{t}, \mathrm{t}}$ & + & 0.0378 & 0.017 & 2.33 & 0.020 \\
\hline $\mathrm{B} / \mathrm{M}$ & - & -0.1989 & 0.046 & -4.28 & 0.001 \\
\hline Industry Dummies & \multicolumn{3}{|c|}{ included } & & \\
\hline Year Dummies & \multicolumn{3}{|c|}{ included } & & \\
\hline \multicolumn{6}{|c|}{ Adjusted $\mathrm{R}^{2}=7.01 \%$} \\
\hline \multicolumn{6}{|c|}{$\begin{array}{l}\text { Beat_low }=\text { Miss_high }: \text { estimate }=0.1078, \mathrm{p} \text {-value }=0.014 . \\
\text { Beat low }=\text { Beat high }: \text { estimate }=0.0885, \text {-value }=0.046 .\end{array}$} \\
\hline
\end{tabular}


Figure 1

Distribution of yearly earnings surprises relative to analysts' consensus forecast (in cents)

Figure 1 shows the distribution of yearly earnings surprises relative to analysts' consensus forecast. The earnings surprise is defined as the difference in cents between a firm's reported earnings per share for the given fiscal year and the I/B/E/S consensus forecast issued during the second month of the firm's fourth quarter. A firm whose earnings where within plus or minus half-a-cent of the consensus forecast would thus have an earnings surprise of zero, while a firm with reported earnings between half a cent and one-and-a-half cents above the consensus forecast would have an earning surprise of one, etc. The figure shows the total number of firms in the sample period, 1988-2001 in a given earnings surprise category. We use raw, unadjusted I/B/E/S data to control for the bias induced by the split-adjusted data.

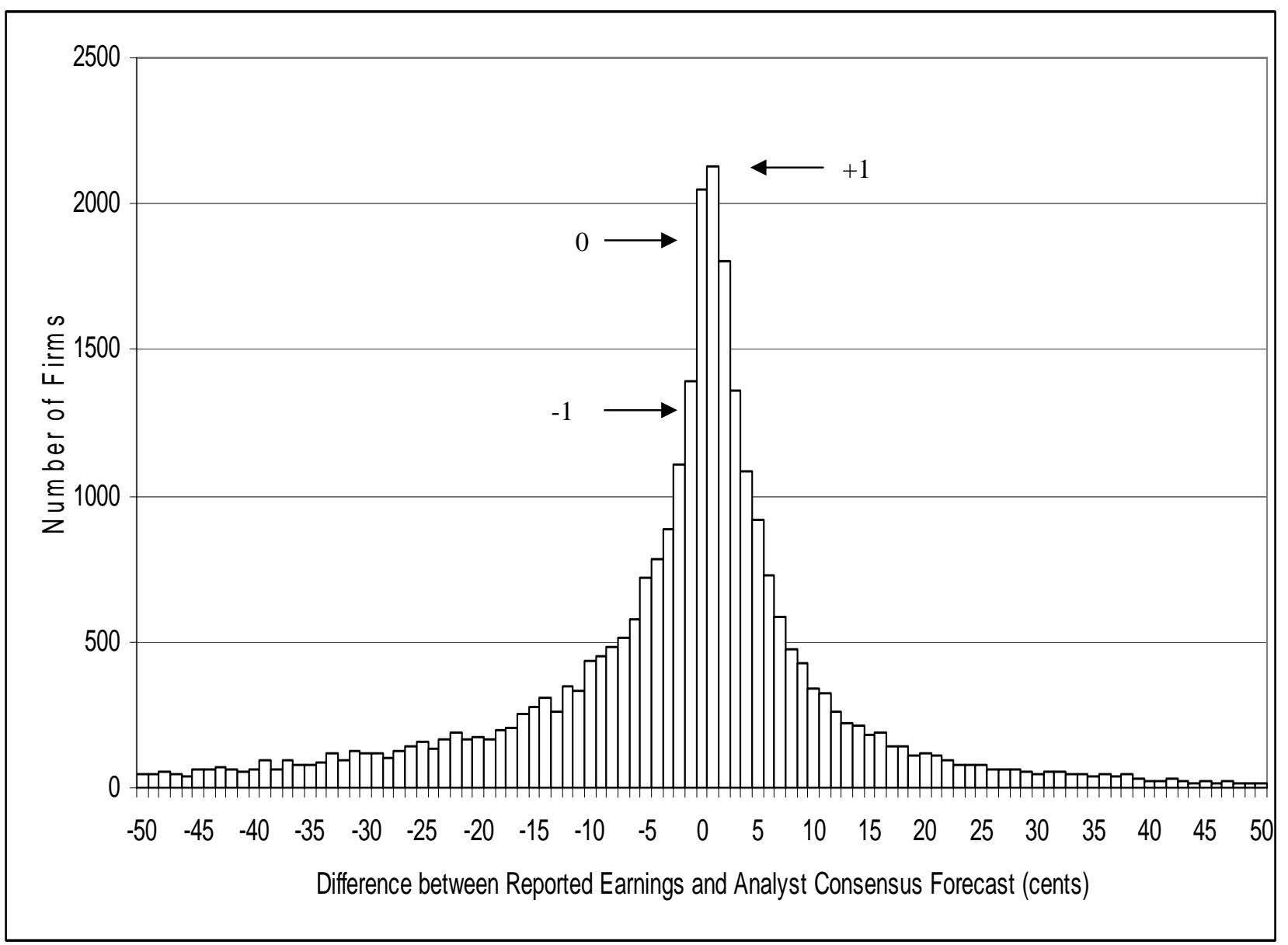




\section{Figure 2}

\section{Risk adjusted monthly size-adjusted returns}

The graphs show the cumulative monthly size adjusted returns for firms with high or low EQSTAT (earnings quality indicator) values that either miss or beat analyst forecasts by a penny. The earnings surprise is defined as the difference in cents between a firm's reported earnings per share for the given fiscal year and the $\mathrm{I} / \mathrm{B} / \mathrm{E} / \mathrm{S}$ consensus forecast issued during the second month of the firm's fourth quarter. "Missing" is defined as having actual earnings between one-and-a-half cent and half a cent below the consensus forecast. "Beating" is defined as having actual earnings between half-a-cent and one-and-a-half cents above the consensus forecast. Earnings quality is measured using EQSTAT. EQSTAT is a ranking from zero to three with a firm receiving one point for each accounting variable, total accruals, change in R\&D, and change in advertising, each scaled by total assets, that is above (below for total accruals) the median level for all firms in a given year. No point is awarded for missing variables. A firm with a rank of three would thus have scaled total accruals below median and scaled change in R\&D and change in advertising above the median. "High" EQSTAT is defined as any firm with a rank of two or three. "Low" EQSTAT is defined as a firm with a rank of zero (no accounting variables on the favorable side of the median). The cumulative return for each individual firm over a particular time interval is calculated using daily CRSP returns and then adjusted by subtracting the cumulative market return of firms in the same CRSP size decile over the same period. Five day adjusted returns are calculated as the adjusted cumulative return beginning two days before the earnings announcement and ending two days after the earnings announcement. Reported returns are the equally weighted average of all size adjusted returns in a given earnings surprise-earnings quality category across the applicable time period. Returns are shown for the five day period around the announcement (5d) and each of the first 36 months following the announcement.

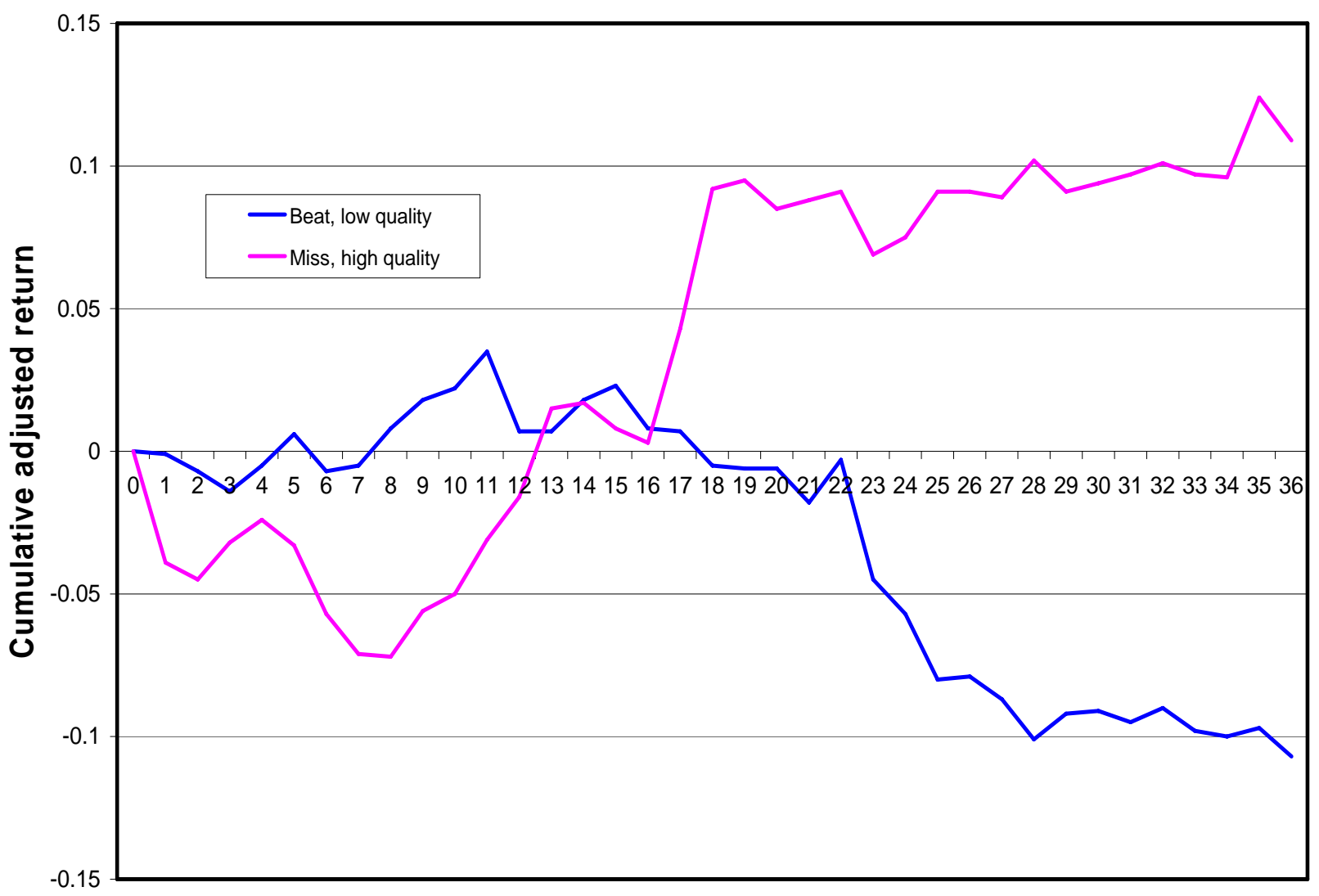

Month relative to earnings release 